Seção Temática: Os Recursos Públicos em Disputa

Volume 11 - 2021 |n. 26

\title{
A Privatização dos Recursos Educacionais através das Escolas Confessionais: uma análise da Cáritas de Rondonópolis/MT
}

\author{
Marilda de Oliveira Costa \\ Universidade do Estado de Mato Grosso (UNEMAT), Cáceres/MT - Brasil \\ Tiago dos Santos Rodrigues \\ Universidade do Estado de Mato Grosso (UNEMAT), Cáceres/MT - Brasil
}

\section{Resumo}

Este artigo é parte de pesquisa em andamento e tem por objetivo mapear e analisar os valores destinados pelo município de Rondonópolis/MT para a organização Cáritas Diocesana de Rondonópolis, entre 2008 e 2019. Fundada na cidade no ano de 1942, a Cáritas anuncia que seu propósito é continuar transformando a sociedade e fornecendo educação básica de qualidade. É uma organização da sociedade civil, filantrópica, sem fins lucrativos, declarada de utilidade pública em nível federal, estadual e municipal. Como previsto na LDB nº 9.394/96 e em acordo com o histórico modelo de atendimento à educação infantil brasileira, a organização recebe subvenção de recursos da Secretaria Municipal de Educação para atendimento à educação infantil, por meio de leis editadas anualmente. Pretende-se demonstrar a movimentação dos gastos, a redução das matrículas subvencionadas na entidade e o aumento do valor aluno da Cáritas comparado ao da rede pública municipal.

Palavras-chave: Confessional. Educação Infantil. Fundo Público.

\section{Privatization of Educational Resources through Confessional}

\section{Schools: an analysis of Cáritas in Rondonópolis-MT}

\begin{abstract}
This article is part of an ongoing research and aims to map and analyze the values allocated by the city of Rondonópolis-MT, for the organization Cáritas Diocesan of Rondonópolis, between 2008 and 2019. Founded in the city in 1942, Cáritas announces that its purpose is to continue transforming society and providing quality basic education. It is a non-profit, philanthropic, civil society organization declared of public utility at the federal, state, and municipal levels. As provided for in LDB No. 9.394/96 and in accordance with the historical model of assistance to early childhood education in Brazil, the organization receives a subsidy from the Municipal Department of Education for assistance to early childhood education, through laws published annually. It is intended to demonstrate the movement of expenses, the reduction of subsidized enrollments in the entity and the increase in the student value of Cáritas compared to the municipal public network.
\end{abstract}

Keywords: Confessional. Child Education. Public Fund. 
A Privatização dos Recursos Educacionais através das Escolas Confessionais

\section{Introdução}

A polêmica em torno da destinação de verbas públicas para o setor privado educacional não é recente, o exemplo mais emblemático se deu no processo constituinte de 1986 e na elaboração da Lei de Diretrizes e Bases da Educação Nacional, Lei n 9.394/96, finalizada no auge das reformas neoliberais no papel do Estado, no Brasil. Mesmo que tal reforma tenha ganhado corpo com as privatizações, as terceirizações de serviços e a introdução da figura jurídica do público não-estatal, que possibilitou ampliar a relação público-privada na educação, aspectos da reforma educacional preservaram direitos garantidos na Constituição Federal de 1988, tal como a integração da Educação Infantil aos sistemas públicos de ensino e o dever do Estado em assegurá-la às crianças de 0 a 3 anos, em creches de 04 a 05 anos ${ }^{1}$, na pré-escola, em consonância com algumas normatizações, dentre elas, o Estatuto da Criança e do Adolescente (Lei $n^{\circ}$ 8.069, de 1990 - ECA), que assinalava propostas de garantias e direitos para a infância e adolescência (Artigos $3^{\circ}$ e $4^{\circ}$ são exemplos da importância conferida a estes dois grupos etários). Nos anos seguintes, o país ampliou o direito à educação e a obrigatoriedade educacional, de quatro a 17 anos, por meio da Emenda Constitucional $n^{\circ} 59 / 2009$, tornando-o direito público subjetivo. Não isento de contradições, a oferta educacional nas diferentes esferas de governo, sobretudo a municipal, tem passado por aprofundamento da bandeira privatista, intensificado com o movimento reformista neoliberal que, frente à adoção de medidas com vistas à ampliação das taxas de lucros do grande capital nacional e estrangeiro, atualmente rejeita princípios democráticos e não mais tolera o Estado liberal.

O tema abordado neste texto é parte desse movimento e tem por objetivo mapear e analisar os valores destinados pelo município de Rondonópolis/MT para a organização Cáritas Diocesana de Rondonópolis, entre 2008 e 2019. É uma organização da sociedade civil, filantrópica, sem fins lucrativos, declarada de utilidade pública em nível federal, estadual e municipal, fundada na cidade de Rondonópolis no ano de 1942. Como previsto na LDB $n^{\circ}$ 9.394/96 e em acordo com o histórico modelo de atendimento à educação infantil brasileira, a organização recebe subvenção de recursos da Secretaria Municipal de Educação para atendimento à educação infantil, por meio de leis editadas anualmente.

A coleta de dados do período entre 2008 e 2020 se deu por meio de consultas a sites oficiais, como o Sistema de Informações sobre Orçamentos Públicos em Educação (SIOPE), o Portal da Transparência do Município, o Laboratório de Dados Educacionais da Universidade Federal do Paraná (UFPR), entre outras fontes. Procurou-se analisar tais dados por meio do cruzamento de matrículas na Educação Infantil (creches e pré-escolas) do Sistema Municipal de Ensino e da entidade privada/filantrópica Cáritas, os recursos próprios do Município destinados à Manutenção e Desenvolvimento do Ensino (MDE) e o percentual desses recursos destinados à Cáritas, assim como o Valor Aluno/Ano (VAA) nas creches e pré-escolas da rede pública municipal de Rondonópolis e o valor de referência adotado na Cáritas. Por fim, procura-se responder à seguinte indagação: a destinação desses recursos à oferta educacional privada, ainda que não comercial, colabora para a ampliação da desigualdade no atendimento das crianças pequenas no município?

1 Pela atual legislação educacional, a matrícula no Ensino Fundamental passa a ser obrigatória a partir dos 6 anos, alterando a educação infantil, anteriormente, de 0 a 6 anos, como inscrito na CF/1988. 
A Privatização dos Recursos Educacionais através das Escolas Confessionais

\section{Direito à educação, relação público-privado e privatização}

A declaração de direitos, entre eles os sociais, tem uma longa trajetória - das lutas operárias por direitos sociais e políticos (séculos XVIII e XIX), tratados e acordos internacionais, às legislações nacionais.

Pode-se considerar que, no caso brasileiro, a Constituição Federal de 1988 (CEF/1988) foi um importante marco no reconhecimento de direitos, dentre os quais o direito educacional e o papel do Estado em assegurá-lo. Tanto a CF/1988 quanto a Lei de Diretrizes e Bases da Educação Nacional, Lei nº 9.394, de 20 de dezembro de 1996, ampliaram o direito à educação a todas as etapas da educação básica.

Ao conceituar o termo educação básica, adotado pela primeira vez no ordenamento jurídico brasileiro, Cury (2008, p. 294) chama atenção à importância dessa medida: "A educação básica é um conceito mais do que inovador para um país que, por séculos, negou, de modo elitista e seletivo, a seus cidadãos, o direito ao conhecimento pela ação sistemática da organização escolar". Estudos de Bourdieu (2014) sobre as desigualdades frente à escola e à cultura repercutiram no mundo todo e categorias por ele criadas, como capital cultural e capital social, ethos, contribuem para explicar o êxito escolar. A explicação das desigualdades educacionais em sociedades marcadamente desiguais, como a brasileira, sobretudo relacionadas ao acesso e ao conhecimento (SAMPAIO; OLIVEIRA, 2015), prescinde de uma análise conjugada de diversos fatores.

Os avanços conquistados na legislação, para assegurar o direito à educação da primeira infância em escolas de educação infantil, somente foram possíveis por meio de lutas históricas de movimentos sociais, Fórum Nacional em Defesa da Escola Pública (FNDEP) e, mais recentemente, do Movimento Interfóruns de Educação Infantil (MIEIB) e a Campanha Nacional pelo Direito à Educação, culminando no reconhecimento da infância como uma fase específica da vida e, como tal, devendo ser cuidada e educada em face de tais especificidades e diversidades, seguindo uma tendência internacional. Ficou estabelecido o direito à educação de crianças de 0 a 3 anos, em creches, e de 4 a 5 anos na pré-escola, as atribuições e responsabilidades dos entes federados em assegurá-la, como prevê o Artigo 11 - $\mathrm{V}$, da LDB $n^{\circ} 9.394 / 96$, e documentos e normas legais, como os planos decenais de educação, que estabelecem metas e estratégias para viabilizar a universalização do atendimento, no caso da pré-escola, em regime de colaboração entre os entes federados.

Os fundos públicos, como o Fundo de Manutenção e Desenvolvimento do Ensino Fundamental e de Valorização do Magistério (FUNDEF), instituído pela Emenda Constitucional $n^{\circ} 14 / 1996$, de 12 de setembro de 1996, regulamenta pela Lei $n^{\circ} 9.424$, de 24 de dezembro do mesmo ano, e pelo Decreto $n^{\circ} 2.264$, de 27 de junho de 1997, impactaram diretamente na oferta da educação infantil pelos municípios. A obrigatoriedade do ensino fundamental se deu em detrimento de outras etapas do ensino (Educação Infantil e Ensino Médio) e de modalidades como a Educação de Jovens e Adultos (EJA), excluídos do referido fundo. Em face ao reconhecido prejuízo daí decorrente para toda a educação básica, tal como previsto no Artigo 205 da Constituição Federal e Artigo $4^{\circ}$, I (Inciso com redação pela Lei nº 12.796, de 04/04/2013), fortaleceu-se no País debates e mobilizações envolvendo entidades acadêmicas, sindicais, movimentos voltados para a defesa do direito à educação da infância, 
A Privatização dos Recursos Educacionais através das Escolas Confessionais

visando a ampliação do financiamento aos demais níveis, etapas e modalidades de toda a educação básica.

Essa ampliação se deu via Fundo de Manutenção e Desenvolvimento da Educação Básica e de Valorização dos Profissionais da Educação (FUNDEB), por meio da Emenda Constitucional $n^{\circ} 53 / 2006$, regulamentada pela Lei $n^{\circ} 11.494 / 2007$ e pelo Decreto $n^{\circ}$ 6.253/2007, em substituição ao FUNDEF. A obrigatoriedade educacional aos alunos entre quatro e 17 anos ganhou capilaridade com a Emenda Constitucional n 59/2009, de 11 de novembro de 2009, regulamentada pela Lei 12.796, de 04/04/2013, ao prever a universalização do atendimento na educação infantil e no ensino médio, consolidando o direito público subjetivo para todas as etapas da educação básica e estabelecendo a matrícula compulsória na educação básica de quatro a 17 anos. Em meio a intensas disputas por destinação de verbas públicas para o setor privado, a Emenda Constitucional 108/2020, regulamentada pela Lei $\mathrm{n}^{\circ} 14.113$, de 25 de dezembro de 2020, tornou o FUNDEB permanente, assegurando a continuidade do financiamento para toda a educação básica pública, com maior aporte financeiro à educação infantil.

O artigo 212 da Constituição Federal Brasileira diz que "[...] a União aplicará, anualmente, nunca menos de dezoito, e os Estados, o Distrito Federal e os Municípios vinte e cinco por cento, no mínimo, da receita resultante de impostos, compreendida a proveniente de transferências, na manutenção e desenvolvimento do ensino" (BRASIL, 1988). O Art. 212, parágrafos $3^{\circ}$ e $5^{\circ}$ da $\mathrm{CF} / 1988$ passou por alterações com a nova redação dada pela Emenda Constitucional $n^{\circ}$ 53/2006 e Emenda Constitucional n 59/2009².

O artigo 70 da Lei de Diretrizes e Base da educação (LDB) aponta que "[...] considerarse-ão como de manutenção e desenvolvimento do ensino as despesas realizadas com vistas à consecução dos objetivos básicos das instituições educacionais de todos os níveis" (BRASIL, 1996). No caso dos municípios brasileiros, a Lei estabelece:

1) Aplicação de no mínimo $25 \%$ da receita de impostos próprios [...] e transferências constitucionais; 2) subvinculação de $20 \%$ de uma cesta de impostos, que a partir de 2007, passou a constituir no âmbito de cada estado o FUNDEB; 3) receita do salário educação; 4) receita de incentivos fiscais; 5) outros recursos previstos em lei (SOUSA; SILVA; LORENSINI, 2016, p. 99).

Os recursos apresentados no item 1, dos $25 \%$ de impostos, têm incidência sobre o Imposto Sobre Serviços de Qualquer Natureza (ISSQN), Imposto Predial e Territorial Urbano (IPTU), Imposto de Renda Retido na Fonte dos Servidores Públicos Municipais (IRRF-SPM), Imposto sobre a Transmissão de Bens e Imóveis (ITBI), essa parte das receitas de impostos que são aplicadas na educação são chamadas de Vinculação Constitucional de recursos e sua aplicação é chamada de Manutenção e Desenvolvimento do Ensino (MDE).

Sousa, Silva e Lorensini (2016, p. 100) reforçam que,

2 Art. $3^{\circ} \mathrm{A}$ distribuição dos recursos públicos assegurará prioridade ao atendimento das necessidades do ensino obrigatório, no que se refere à universalização, garantia de padrão de qualidade e equidade, nos termos do plano nacional de educação (NR).

Art. $5^{\circ}$ Para efeito do cálculo dos recursos para manutenção e desenvolvimento do ensino de que trata o art. 212 da Constituição, o percentual referido no caput deste artigo será de $12,5 \%$ (doze inteiros e cinco décimos por cento) no exercício de 2009, 5\% (cinco por cento) no exercício de 2010, e nulo no exercício de 2011 (NR). 
A Privatização dos Recursos Educacionais através das Escolas Confessionais

As transferências constitucionais no caso dos municípios, compreendem o Fundo de Participação dos Municípios (FPM) formado pela partilha de 23,5\% do Imposto sobre Renda (IR) e do Imposto sobre Produtos Industrializados (IPI). Os municípios recebem ainda $50 \%$ da arrecadação do Imposto sobre a Propriedade de Veículos Automotores (IPVA), licenciados em seus territórios e $25 \%$ do produto de arrecadação do imposto sobre operações relativas à circulação de mercadorias e sobre prestação de serviços de transporte interestadual e intermunicipal de comunicação (ICMS).

O direcionamento dos recursos destinados à educação impacta diretamente na qualidade da oferta educacional, no direito à educação e, contraditoriamente ao que tem mostrado a trajetória internacional com as reformas neoliberais em curso desde início dos anos 1980, em países de capitalismo avançado, como Inglaterra e Estados Unidos e o avanço de diversas formas de privatização da educação nos referidos países, o Brasil avançou na definição de fundos públicos para assegurar o direito à educação e a obrigatoriedade educacional de sete a 14 anos, em um primeiro momento e, posteriormente, ampliou para toda a educação básica, de quatro a 17 anos, mesmo em um contexto de reformas neoliberais, no País e na América do Sul. Os experimentos iniciais neste continente se deram na ditadura chilena e na Bolívia (ANDERSON, 1995). Os princípios, fundamentos, origens e implicações do neoliberalismo têm sido objeto de estudo de inúmeros pesquisadores, dentre eles, Dardot e Laval (2016) e Puello-Socorrás (2008).

As implicações das medidas neoliberais para o Estado e a administração pública resultam em processos de terceirização e privatização cada vez mais crescentes e diversificados e, em razão do nível de desmontes em diversas áreas, decidiu-se aqui os chamar de "contrarreformas", como definiu Borón (2000, p. 121):

[...] as democracias 'falsas' da América Latina estão sofrendo o embate não de 'reformas orientadas para o mercado', como são eufemisticamente chamadas, mas sim de uma autêntica contra-reforma social disposta a ir a qualquer extremo para preservar e reproduzir as estruturas de desigualdade social e econômica em nossa região.

Trata-se, portanto, de reorganização de processos de acumulação do capitalismo em crise e não propriamente de reformas, se por reforma entendemos a busca de melhorias, avanços de direitos, democratização política e econômica, dentre outros fatores. As reformas têm mostrado, sobretudo em países da América Latina, o sucateamento de setores inteiros, sendo a educação pública convertida em serviço a ser negociado na "bacia das almas", por ser considerada um setor que pode proporcionar lucro às grandes corporações, além da ingerência do mercado no conteúdo da educação.

Como aponta Borón (1995, p. 78), “[...] a hegemonia ideológica do neoliberalismo e sua expressão política, o neoconservadorismo, adquiriram uma desabitual intensidade na América Latina. Um de seus resultados foi o radical enfraquecimento do Estado", cuja finalidade foi/é atender aos interesses das classes dominantes, essa crise "[...] se acrescenta no discurso ideológico auto-incriminatório que iguala tudo que é estatal com a ineficiência, a corrupção e o desperdício, enquanto a iniciativa privada aparece como a esfera da eficiência, da probidade e da austeridade" (BORÓN, 1995, p. 78). Segundo o autor, essas falácias não resistem a uma pequena análise, pois a corrupção dentro do Estado tem parceria com o setor privado e grandes empresários.

As reformas neoliberais dos anos 1990 tiveram maior acolhida no Brasil nos governos Fernando Henrique Cardoso, do PSDB (1995 a 2002). Na área econômica, iniciaram-se 
A Privatização dos Recursos Educacionais através das Escolas Confessionais

grandes processos de privatizações em diversos setores, terceirizações de serviços e, na área educacional, a figura jurídica do público não-estatal deu início a uma nova história na relação público-privada e a educação não ficou imune às ingerências neoliberais, como analisou Peroni (2003), sobre a política educacional da referida década. Desde então, mesmo que essa relação não estivesse ausente da área educacional, nas três esferas de governo, o alargamento de processos de privatização na área educacional tem se tornado mais evidente a partir de 2016, com o golpe de Estado.

Ante os diversos sentidos atribuídos à privatização, esclarece-se que não se trata somente da venda direta de uma empresa estatal ou bem público para a iniciativa privada, os processos de privatização são muito mais articulados e muitas vezes podem até passar despercebidos, como as denominadas privatizações endógenas e exógenas (BALL; YOUDELL, 2007). O reforço adicional foi possibilitado com a aprovação da Lei $n^{0} 11.079$, sancionada em dezembro de 2004: "Art. $1^{\circ}$ Esta Lei institui normas gerais para licitação e contratação de parceria público-privada no âmbito dos Poderes da União, dos Estados, do Distrito Federal e dos Municípios" (BRASIL, 2004, p. 01).

Adrião (2018) esclarece que o termo "parceria" tem um papel de acobertamento da real ideia de privatização, dificultando assim sua explicação.

\begin{abstract}
A começar pelo fato de não se tratar de relação colaborativa entre setores que atuariam horizontalmente, como à primeira vista o termo 'parceria' pode indicar. Tampouco se trata de formas específicas de privatização sugeridas pelo Banco Mundial (BM), as quais no Brasil foram reguladas pela Lei Federal $n^{\circ} 11.079$ de 30/12/04. Trata-se de processos pelos quais a educação pública brasileira, entendida como aquela financiada e gerida pelo Poder Público, conforme indicado na Lei de Diretrizes e Bases - No 9 394/1996, subordinase formal e concretamente ao setor privado com fins de lucro (ADRIÃO, 2018, p. 09).
\end{abstract}

Em outra definição, Ball e Youdell (2007, p. 03) utilizam os termos "Privatización Encubierta en La Educación Pública", para se referir a essas formas "secretas" ou "encobertas" de privatização. As abordagens dos processos de privatização têm viés no Estado Mínimo e no Livre Mercado, o reducionismo estatal, abrindo espaço para a ação da iniciativa privada. Os autores consideram dois tipos principais de privatização, as endógenas, ou endoprivatização, e as exógenas, ou exoprivatizações. As privatizações endógenas são definidas como:

[...] a importação de ideias, métodos, práticas do setor privado para tornar o setor público cada vez mais como empresa e cada vez mais comercial [...] A primeira forma de privatização, segundo a qual o setor público é solicitado a comportar-se cada vez mais como o setor privado, generalizado e tão bem consolidado (BALL; YOUDELL, 2007, p. 13).

Esse tipo de privatização acontece de dentro para fora da própria instituição ou setor, pode ser colocado quando as lógicas de competição do mercado são inseridas nas escolas públicas na busca por resultados mais satisfatórios com baixo custo. Ranqueamento, estandardização dos resultados de avaliações, gratificações por desempenho, são alguns exemplos que podem ser utilizados para explicar o que seriam as endoprivatizações.

As exoprivatizações "[...] envolvem a abertura dos serviços de educação pública à participação do setor privado, através de modalidades baseadas no benefício econômico, bem como na utilização do setor privado em termos de concepção, gestão ou provisão, diferentes aspectos da educação pública" (BALL; YOUDELL, 2007, p. 13). Essa segunda forma de 
A Privatização dos Recursos Educacionais através das Escolas Confessionais

privatização da educação pode ser considerada a mais recente, porém é a que mais está se expandindo. Os autores apontam que, para muitos, tanto o primeiro quanto o segundo tipo não são considerados processos de privatização.

Nas formas atuais, o neoliberalismo tem se associado ao conservadorismo como expressão máxima da política global: conservadorismo em valores e neoliberalismo na economia

[...] tem sido responsável pelo impulso (contra) reformador ofensivo pelo Capital contra todos os direitos sociais historicamente alcançados. O papel do Estado está sendo mais uma vez - redefinido, apoiando uma nova forma de administração pública alinhada (e por que não dizer também: alienado) com uma forma renovada de neoliberalismo mais feroz e agressivo do que em contraste e comparação com suas versões anteriores (PUELLO-SOCORRÁS, 2008, p. 25, tradução nossa).

O agravamento desse contexto se deu com a emergência da pandemia do coronavírus (Sars-Cov2), cujas consequências para a saúde, a economia, o trabalho e a renda, o aprofundamento da privatização da educação, só para citar alguns aspectos, é a expressão mais cruel do capitalismo neoliberal.

\section{Escolas confessionais no Brasil - considerações sobre a organização Cáritas}

A História da Educação brasileira vincula-se à história das organizações educativas confessionais, desde os anos de colonização portuguesa. A expulsão dos jesuítas do País, em 1758, não significou a ausência de aulas em conventos e mosteiros de outras ordens religiosas; reforçado pela criação de mais dioceses, surgiram os seminários episcopais (MONLEVADE, 1997). Pinto (2018) indica que a educação brasileira já passava por processos de privatização desde o período colonial "[...] o atendimento [...] foi terceirizado aos jesuítas que recebiam, como contrapartida, o monopólio do ensino em Portugal e em todo o reino" (PINTO, 2018, p. 848).

Após 200 anos, aproximadamente, de educação pública de concessão aos jesuítas, diversas reformas educacionais foram marcadas por tentativas, todas frustradas, de dar maior organicidade à educação nacional. Sob influência da escola nova, educadores brasileiros lideraram um movimento político e pedagógico que culminou com o Manifesto dos Pioneiros da Educação Nova de 1932, cuja relevância e capilaridade, além de influenciar o capítulo da educação na Constituição Federal de 1934, possibilitou maior organicidade à educação nacional - um programa educacional completo para o País. Esse movimento foi marcado por fortes embates entre educadores liberais e católicos: de um lado, os liberais estavam cientes das transformações da sociedade brasileira e da necessidade de "modernização", com forte apelo ao desenvolvimento interno. Nesse contexto, pela primeira vez a escola fora chamada a desenvolver uma função social; por outro lado, os católicos se articularam com o argumento da defesa do direito da família à escolha da escola para os filhos, ou seja, combateram o papel do Estado como provedor da educação pública, acusando os liberais de advogarem pelo monopólio do Estado na área educacional (ROMANELLI, 1998).

Por longo período, como afirma Cury (2005), o sistema público de ensino caminhou lado a lado com o privado, sem conflitos, e não representou empecilho ao desenvolvimento deste último. Somente nos anos 1980, época em que alguns segmentos da sociedade civil se 
A Privatização dos Recursos Educacionais através das Escolas Confessionais

organizaram e articularam em defesa da escola pública e oposição à ditadura militar, os embates tiveram nova tonalidade.

Nota-se que as possibilidades de destinação de recursos públicos ao setor privado sem fins lucrativos, conforme assegurado na Constituição de 1988, resultaram de correlação de forças entre os movimentos que congregaram o Fórum de Educação na Constituinte em Defesa do Ensino Público e Gratuito e os dissidentes desse movimento, vinculados à Igreja, que apoiavam as escolas comunitárias (GOHN, 2001). Essa ruptura provocou mudanças na denominação do Fórum, passando a se chamar Fórum em Defesa da Escola Pública (FNDEP), nele continuando alguns "representantes da tendência vinculada à Igreja por intermédio das suas entidades de classe" (PERONI, 2003). Conforme registros de Peroni (2003), as principais forças que se opuseram ao FNDEP foram as escolas particulares privadas, por meio da Federação Nacional de Estabelecimentos de Ensino (FENEM), e o setor privado confessional, por intermédio da Associação Brasileira de Escolas Superiores Católicas (Abesc) e da Associação da Educação Católica (AEC). Conforme registrado acima, "[...] a polêmica com a Igreja Católica tem ocorrido desde o Manifesto dos Pioneiros, só que, na década de 1990, foi criada uma nova perspectiva jurídica, a das escolas comunitárias" (PERONI, 2003, p. 76); "[...] as escolas ditas comunitárias defenderam na Constituinte a ideia da não-exclusividade das verbas públicas para entidades públicas" (GOHN, 2001, p. 85). Conforme o Art. 213 da Constituição Federal de 1988, o FNDEP não teve força política para barrar a bandeira privatista em sua totalidade, tal como segue:

\footnotetext{
Os recursos públicos serão destinados às escolas públicas, podendo ser dirigidos a escolas comunitárias, confessionais ou filantrópicas, definidas em lei, que:

I - Comprovem finalidade não-lucrativa e apliquem seus excedentes financeiros em educação;

II - Assegurem a destinação de seu patrimônio a outra escola comunitária, filantrópica ou confessional, ou ao Poder Público, no caso de encerramento de suas atividades (BRASIL, 1988).
}

Tal como na Constituinte, a elaboração da LDB 9.394, de 20 de dezembro de 1996, teve início em um momento privilegiado de participação na definição de políticas públicas "até então restritos à sociedade política" (PERONI, 2003, p. 79). Foram três os principais atores representantes da sociedade civil no processo: os denominados publicistas (Fórum Nacional em Defesa da Escola Pública na LDB (FNDEP)); os privatistas (Confederação Nacional dos Estabelecimentos de Ensino (Confenen)) e os confessionais (Associação Brasileira de Escolas Superiores Católicas (Abesc); Associação de Educação Católica do Brasil (AEC) e Confederação Nacional dos Bispos do Brasil (CNBB)) (ROCHA, 1993 apud PERONI, 2003). Tal processo foi alterado a partir de 1995, com a vitória eleitoral de Fernando Henrique Cardoso do PSDB (PERONI, 2003), possibilitando a destinação de recursos públicos nas situações apontadas no Artigo 213, incisos I e II, da Constituição Federal de 1988, sem, no entanto, barrar a ampliação desse processo para outras entidades do terceiro setor. É nesse contexto que se situa a subvenção de recursos financeiros à Cáritas Diocesana de Rondonópolis.

Segundo o site da instituição, a Cáritas Diocesana de Rondonópolis foi fundada em agosto de 1942 e registrada em Cuiabá em 08/02/1951. A Cáritas Diocesana é uma organização da sociedade civil (OSC), filantrópica, sem fins lucrativos, declarada de utilidade pública a nível federal, estadual e municipal. Iniciou suas atividades na educação infantil de 
A Privatização dos Recursos Educacionais através das Escolas Confessionais

Rondonópolis no ano de 1979, subsidiada anteriormente pela Fundação Estadual do BemEstar do Menor de Mato Grosso (FEBEMAT). Atualmente a instituição mantém cerca de 5 unidades de atendimento à educação infantil, com diversos subsídios, dentre eles o apoio da Prefeitura de Rondonópolis.

\section{Características do município de Rondonópolis e o Sistema Municipal de Ensino}

Rondonópolis é um município que se encontra localizado na região Sudoeste do estado de Mato Grosso, na região Centro-Oeste do Brasil. De acordo com dados do Instituto Brasileiro de Geografia e Estatística (IBGE) do ano de 2020, o município possui uma população estimada em 236.042 habitantes; segundo o Atlas de Desenvolvimento Humano do Brasil, o Índice de Desenvolvimento Humano é de 0,755 , sendo considerado um índice de médio a bom. A escolarização de crianças de 6 a 14 anos está em torno de 98,4\%, ainda conforme o senso de 2010. Possui um Produto Interno Bruto de $\mathrm{R} \$ 11.223 .536,00$, atualizado no ano de 2018, e um PIB per capita de $\mathrm{R} \$ 49.041,70$, atualizado em 2018. Considerada por muitos como a capital do agronegócio, assim como a base de expansão de demais segmentos econômicos desenvolvidos na região, principalmente voltados para a indústria.

O Sistema de Educação do Município de Rondonópolis foi instituído pela Lei Municipal $n^{\circ}$ 9.077, de 01 de dezembro de 2016, e o Conselho Municipal de Educação, instituído pela Lei Municipal $n^{\circ}$ 9.352, de 17 de julho de 2017, consiste num órgão colegiado de caráter normativo, deliberativo, fiscalizador e consultivo.

Conforme dados educacionais de 2019, disponíveis nas Sinopses Estatísticas do Inep, o município possui 67 escolas, 20.975 alunos matriculados no Ensino Fundamental, 9.017 alunos matriculados na Educação Infantil e 1.275 professores. Como se vê, o número total de alunos matriculados na educação pública representa $8.88 \%$ da população municipal, já a educação infantil equivale a $3,8 \%$ da população municipal.

A manutenção desse sistema, bem como a subvenção ao setor privado sem fins comerciais serão tratadas a seguir.

\section{Mapeamento das receitas e despesas com educação - subvenção financeira à Cáritas Diocesana de Rondonópolis}

O município de Rondonópolis mantém subvenção financeira à instituição Cáritas Diocesana com repasses mensais estabelecidos por leis municipais editadas periodicamente com valores diversificados e que, desde 2007, acompanham a ordem dos milhões.

Alguns dados disponibilizados podem apresentar variações em relação à série histórica, pois as legislações utilizadas da subvenção mapeiam os valores a partir de 2008. Porém, o valor aplicado em 2008 começa com uma lei sancionada em 2007, e alguns dados educacionais básicos estão disponíveis de 2008 até o ano de 2019, levando em consideração que as sinopses estatísticas do Inep do ano de 2020 ainda não estão disponíveis para consulta ou download.

Para entender melhor sobre como funciona a arrecadação no âmbito municipal, foram elaborados e organizados alguns dados que facilitam o entendimento das receitas e despesas municipais relacionadas à educação infantil, tendo em foco o MDE. O Gráfico abaixo mostra 
A Privatização dos Recursos Educacionais através das Escolas Confessionais

os valores indexados do total de impostos destinados aos gastos com educação no município de Rondonópolis de acordo com o Art. 212 da Constituição Federal.

Gráfico 1 - Receita total ${ }^{3}$ de impostos do município de Rondonópolis - 2010 a 2019

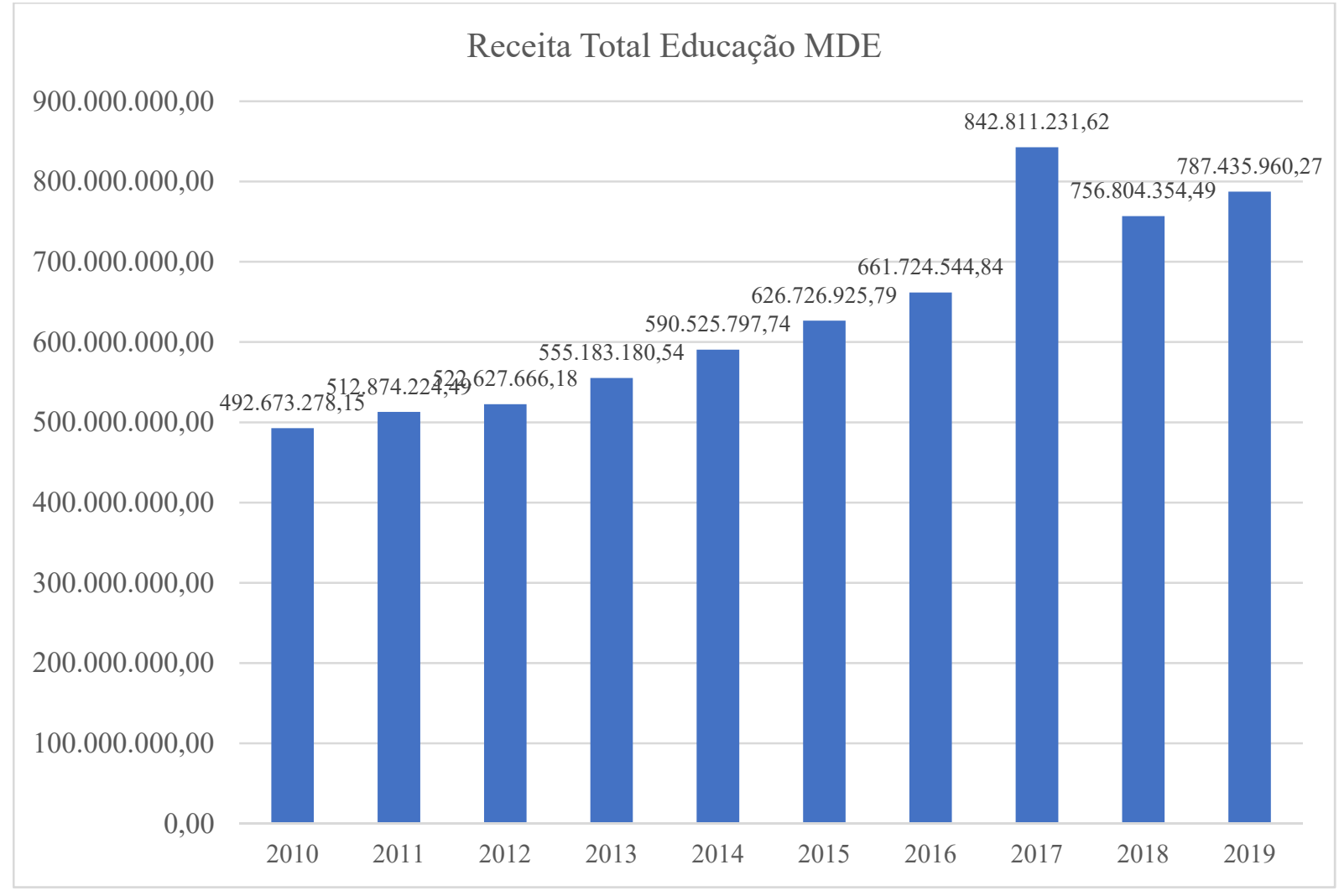

Fonte: Elaboração própria com base em dados disponíveis em:

https://www.fnde.gov.br/siope/demonstrativoMDEMunicipal.do?acao=pesquisar\&pag=result\&cod_uf=51\&municipios=510562.

É visível que a receita municipal é alta, tendo em vista que o município possui a segunda maior arrecadação do estado, ficando atrás apenas da capital Cuiabá, porém é importante ressaltar aqui que uma arrecadação alta pode não significar que a aplicação na educação seja mais eficiente do que a de outros municípios de menor renda por exemplo, hipótese que não será desenvolvida neste texto. No segundo gráfico elaborado estão apresentados os gastos totais municipais com educação provenientes dos recursos do MDE. Dentro desses recursos encontram-se as verbas utilizadas para a subvenção financeira da Cáritas Diocesana.

3 Valores corrigidos pelo Índice Nacional de Preços ao Consumidor Amplo (IPCA). 
A Privatização dos Recursos Educacionais através das Escolas Confessionais

\section{Gráfico 2 - Evolução das despesas totais com educação e educação infantil proveniente do} MDE - 2009 a 2019

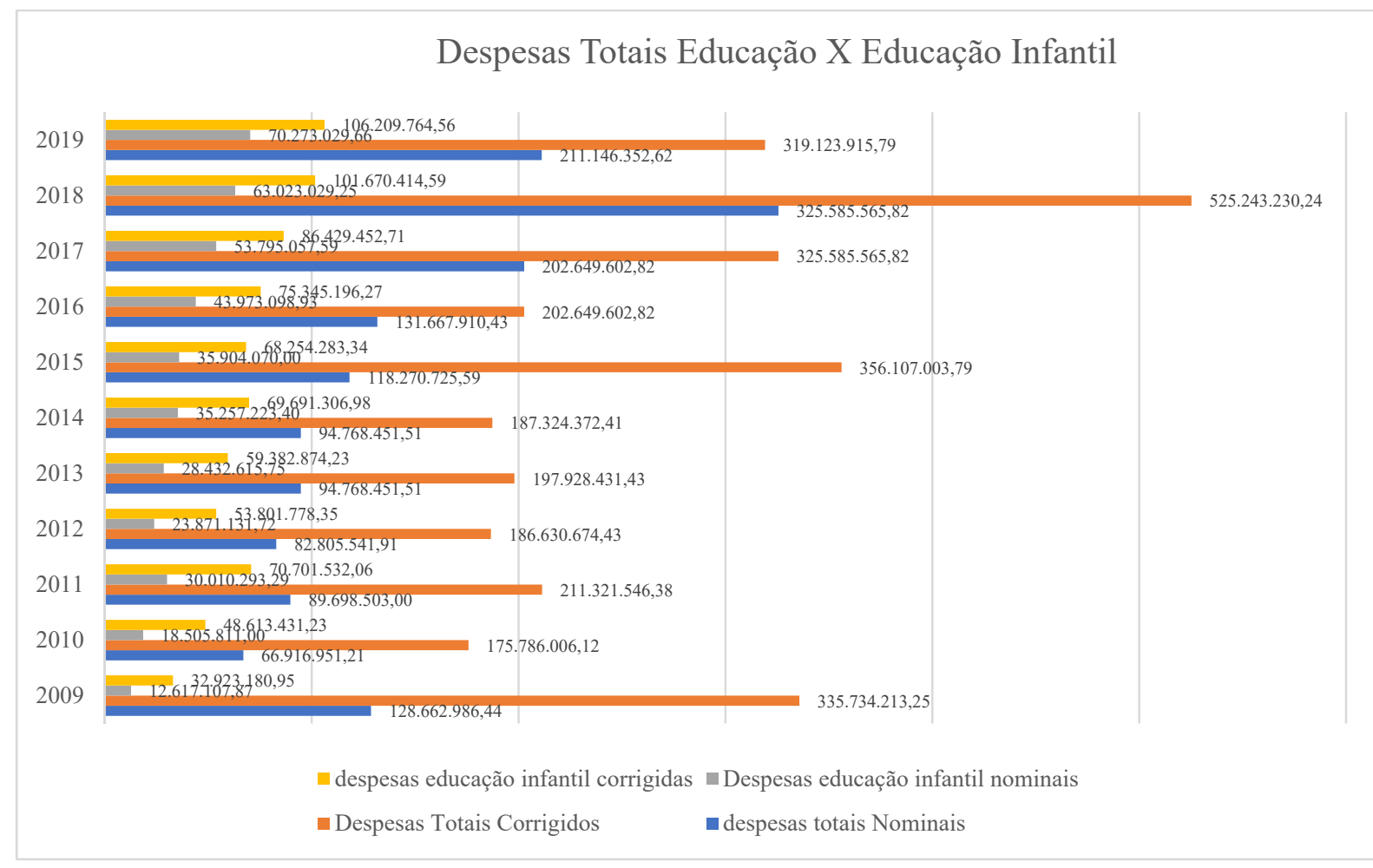

Fonte: Elaboração própria com base em dados disponíveis em:

https://www.fnde.gov.br/siope/demonstrativoMDEMunicipal.do?acao=pesquisar\&pag=result\&cod_uf=51\&municipios=510562.

Em 2009 as despesas superavam os 100 milhões, porém houve uma queda de $48 \%$ em 2010, mantendo-se abaixo dos 100 milhões até o ano de 2013; em 2014 houve um aumento significativo em relação ao ano anterior e, a partir de 2016 até 2020, o crescimento foi gradativo, atingindo a marca de mais de 200 milhões em despesas a partir de 2019. De 2009 até o ano de 2020 houve um aumento de $77,69 \%$ nas despesas somente com MDE.

O Gráfico 3 traz a evolução dos recursos destinados somente à educação infantil do município, provenientes das receitas totais do MDE. Esses dados foram organizados com os resultados enviados do município, disponíveis no SIOPE, facilitando assim uma visão total dos recursos, de maneira a possibilitar a análise dos gráficos e tabelas que mostram como esses recursos foram destinados. Foram separadas apenas as arrecadações para a educação infantil, não entrando os repasses dos Fundeb. 


\section{Gráfico 3 - Evolução dos recursos de educação infantil Rondonópolis - 2009 a 2019}

\section{Recursos Próprios Educação Infantil exceto FUNDEB}

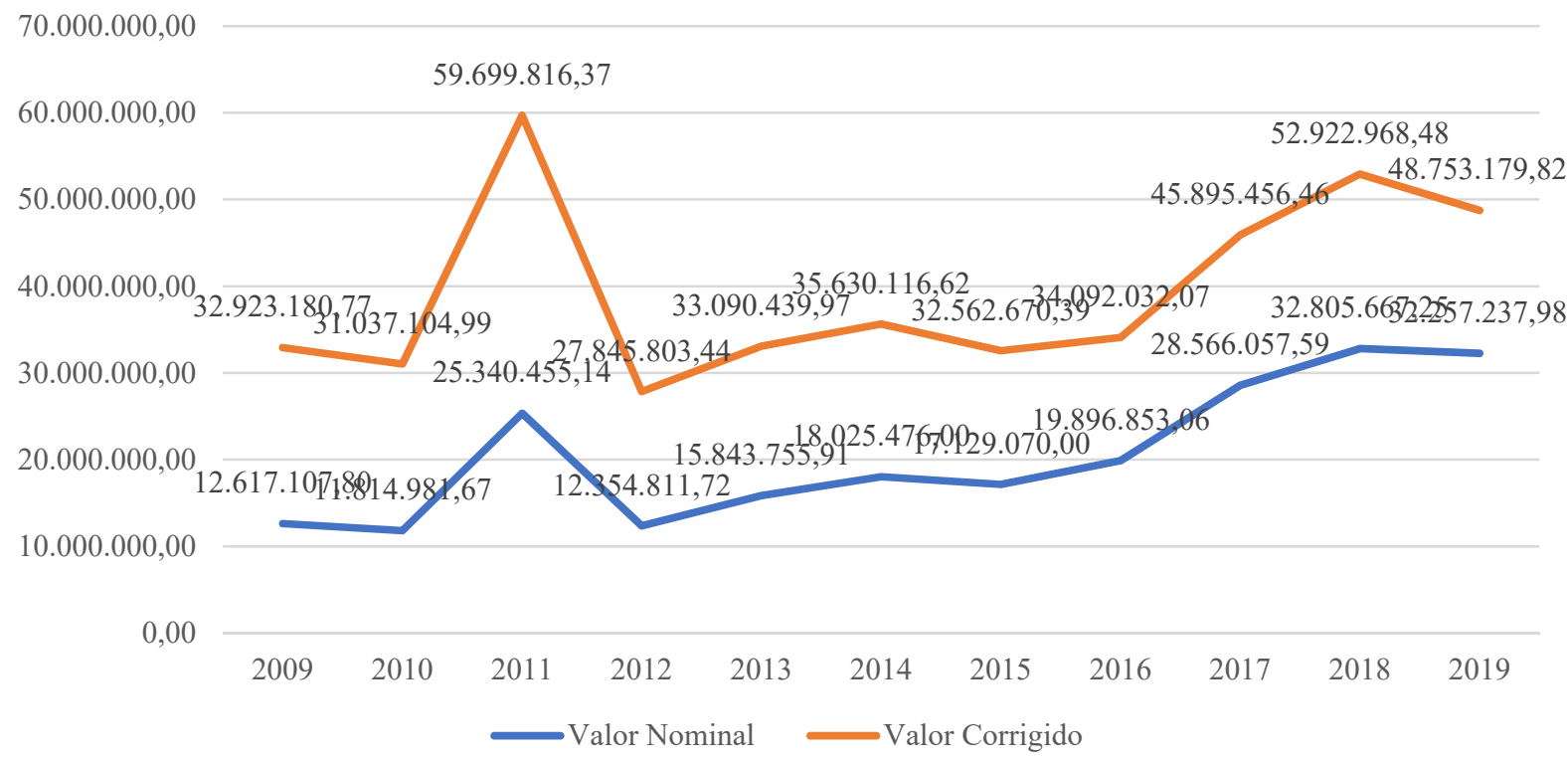

Fonte: Elaboração própria com base em dados disponíveis em:

https://www.fnde.gov.br/siope/demonstrativoMDEMunicipal.do?acao=pesquisar\&pag=result\&cod_uf=51\&municipios=510562.

A maior concentração de recursos arrecadados no município e destinados à educação infantil deu-se nos anos de 2011, 2017, 2018 e 2019.

O Quadro 1, a seguir, traz o detalhamento das leis ordinárias municipais que concedem subvenção financeira à Cáritas Diocesana por meio dos repasses com valores anuais já determinados no ano anterior.

Quadro 1 - Repasses à Cáritas diocesana Rondonópolis - 2007 a 2019

\begin{tabular}{|c|c|c|c|}
\hline Legislação/ Ano & Valor mensal & Parcelas & Total \\
\hline $\begin{array}{l}\text { Lei } n^{\circ} 5.321 \text {, de } 14 \text { de dezembro de } \\
2007^{4}\end{array}$ & $100.000,00$ & 11 & $1.100 .000,00$ * \\
\hline $\begin{array}{l}\text { Lei } n^{\circ} 5.653, \text { de } 20 \text { de fevereiro de } \\
2009 .\end{array}$ & $244.885,77$ & 11 & $2.693 .743,47^{*}$ \\
\hline $\begin{array}{l}\text { Lei } n^{\circ} 6.065 \text {, de } 15 \text { de dezembro de } \\
2009 .\end{array}$ & $270.000,00$ & 12 & $3.240 .000,00^{*}$ \\
\hline $\begin{array}{l}\text { Lei } n^{\circ} 6.542 \text {, de } 09 \text { de dezembro de } \\
2010\end{array}$ & $300.000,00$ & 12 & $3.600 .000,00^{*}$ \\
\hline Lei ${ }^{\circ} 6.686$, de 28 de abril de 2011 & $322.000,00$ & 8 & $2.576 .000,00^{*}$ \\
\hline $\begin{array}{l}\text { Lei } n^{\circ} 6.950 \text {, de } 10 \text { de novembro de } \\
2011 .\end{array}$ & $372.000,00$ & 2 & $744.000,00^{*}$ \\
\hline $\begin{array}{l}\text { Lei } n^{\circ} 6.993, \text { de } 09 \text { de dezembro de } \\
2011\end{array}$ & $360.000,00$ & 12 & $4.320 .000,00^{*}$ \\
\hline $\begin{array}{l}\text { Lei } n^{\circ} 7.495 \text {, de } 07 \text { de dezembro de } \\
2012 .\end{array}$ & $300.000,00$ & $\begin{array}{l}\text { Não especificado } \\
\text { estimam-se } 12\end{array}$ & $3.600 .000,00$ \\
\hline Lei $n^{\circ} 7.565$, de 24 de janeiro de 2013. & $258.333,33$ & 12 & $3.099 .999,96^{*}$ \\
\hline $\begin{array}{l}\text { Lei } n^{\circ} 7.920, \text { de } 05 \text { de dezembro de } \\
2013 .\end{array}$ & $218.038,91$ & 12 & $2.616 .466,92^{*}$ \\
\hline
\end{tabular}

4 Destinada ao atendimento da educação infantil e salas de aula do Projeto EJA Educação de Jovens e Adultos, ambos mantidos pela citada entidade. 
A Privatização dos Recursos Educacionais através das Escolas Confessionais

\begin{tabular}{|c|c|c|c|}
\hline $\begin{array}{l}\text { Lei } n^{\circ} 8.318 \text {, de } 19 \text { de dezembro de } \\
2014\end{array}$ & $189.594,00$ & 12 & $2.275 .128,00$ \\
\hline $\begin{array}{l}\text { Lei } n^{\circ} 8.594 \text {, de } 11 \text { de setembro de } \\
2015 .\end{array}$ & $40.771,00$ & 4 & $122.313,00$ \\
\hline $\begin{array}{l}\text { Lei } n^{\circ} 8.717 \text {, de } 18 \text { de dezembro de } \\
2015 .\end{array}$ & $173.700,63$ & 12 & $2.084 .407,56$ \\
\hline $\begin{array}{l}\text { Lei } n^{\circ} 9.067 \text {, de } 11 \text { de novembro de } \\
2016\end{array}$ & $205.259,98$. & 11 & $2.257 .859,78$ \\
\hline Lei $n^{\circ} 9.542,14$ de dezembro de 2017. & $209.325,28$. & 12 & $2.511 .521,24$ \\
\hline $\begin{array}{c}\text { Lei } n^{\circ} 10.041, \text { de } 14 \text { de novembro de } \\
2018 .\end{array}$ & $251.255,34$ & 11 & $2.763 .808,74$ \\
\hline $\begin{array}{l}\text { Lei } n^{\circ} 10.651 \text {, de } 05 \text { de dezembro de } \\
2019 .\end{array}$ & $262.404,68$ & 11 & $2.886 .451,48$ \\
\hline $\begin{array}{l}\text { Lei } n^{\circ} 11.236, \text { de } 22 \text { de dezembro de } \\
2020 .\end{array}$ & $256.737,03$ & 11 & $2.824 .107,33$ \\
\hline
\end{tabular}

*Não mencionado. Estimam-se valores aproximados de acordo com o número de parcelas. Fonte: Elaboração própria com base em dados disponíveis em: https://leismunicipais.com.br/prefeitura/mt/rondonopolis?o=\&q=C\%C3\%A1ritas.

Ainda que as leis ordinárias sejam publicadas anualmente para subvenção mensal, destaca-se que em alguns anos, como 2009, 2011 e 2015, há mais de um ordenamento de verbas destinadas ao atendimento da educação infantil pela Cáritas Diocesana, que não são especificados como crédito suplementar na lei, apenas como repasse regular.

Para melhor compreensão, o Gráfico 4, a seguir, mostra a evolução da porcentagem dos recursos destinados à instituição, tendo como base de cálculo o Gráfico 3, em relação aos valores demonstrados no Quadro 1.

\section{Gráfico 4 - Percentual dos recursos da educação infantil destinados à Cáritas diocesana entre 2009 e 2020}

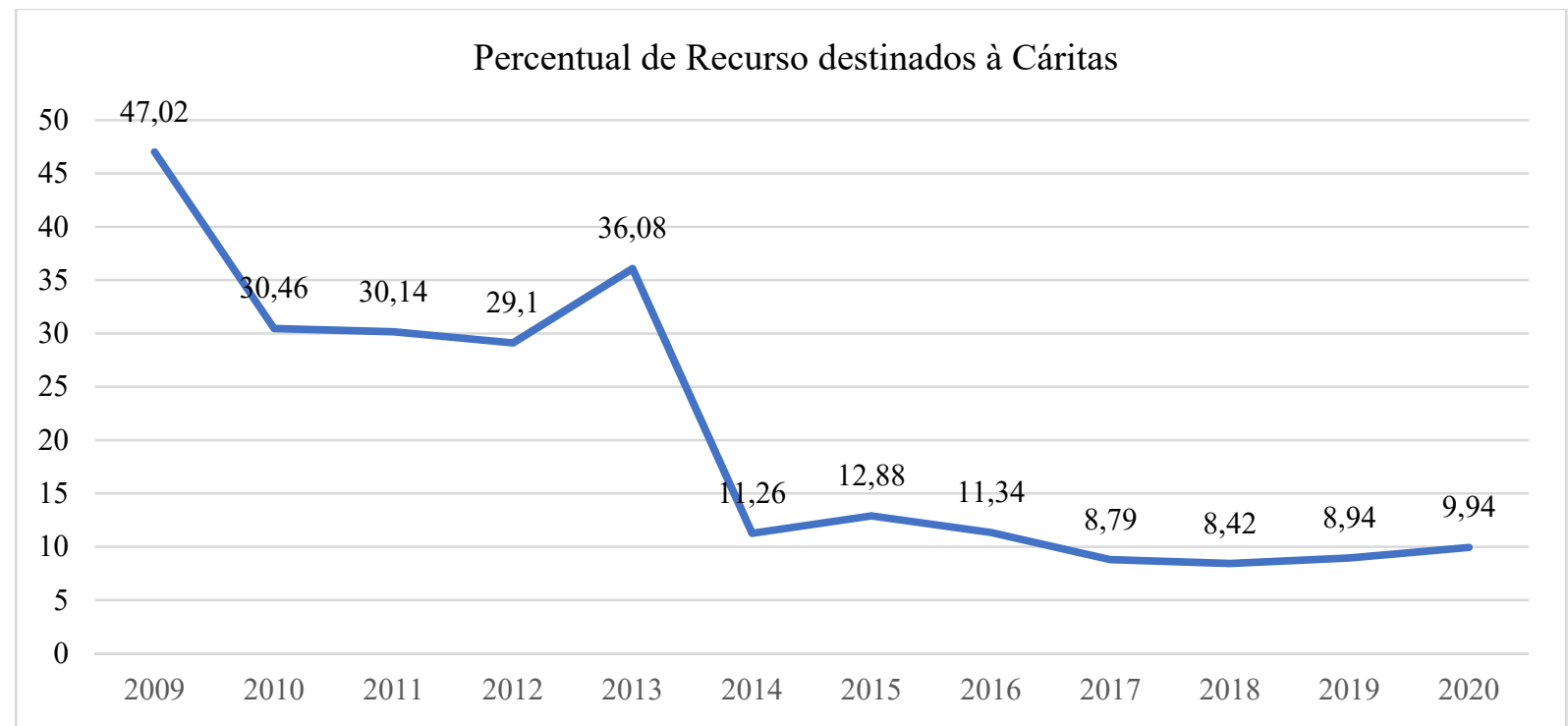

Fonte: Elaboração própria.

A trajetória dos recursos subvencionados à Cáritas, no período analisado, mostra oscilação nos valores, chegando a percentuais próximos de $50 \%$ dos recursos do MDE repassados para a instituição no ano de 2009 , porém há de se levar em consideração que, no mesmo ano, a entidade manteve $66,5 \%$ das matrículas de educação infantil pública do município, como será apresentado no Gráfico 6. 
A Privatização dos Recursos Educacionais através das Escolas Confessionais

A tabela a seguir mostra dados importantes no que diz respeito à correção monetária dos valores de acordo com índices inflacionários e desvalorização da moeda nacional. Nela ficam esclarecidos os valores dos repasses mensais e anuais de acordo com Índice Geral de Preços-Mercado (IGP-M) da Fundação Getúlio Vargas de abril de 2021.

Tabela 1 - Correção monetária IGP-M (FGV) valor repasse - 2008 a 2019

\begin{tabular}{cccc}
\hline Ano & Valor nominal & $\%$ & Valor corrigido \\
\hline $\mathbf{2 0 0 8}$ & $1.100 .000,00$ & 148,36 & $2.732 .001,36$ \\
$\mathbf{2 0 0 9}$ & $5.933 .743,47$ & 146,94 & $14.736 .790,30$ \\
$\mathbf{2 0 1 0}$ & $3.600 .000,00$ & 126,28 & $9.456 .940,44$ \\
$\mathbf{2 0 1 1}$ & $7.640 .000,00$ & 114,63 & $17.999 .147,82$ \\
$\mathbf{2 0 1 2}$ & $3.600 .000,00$ & 99,67 & $8.113 .834,08$ \\
$\mathbf{2 0 1 3}$ & $5.716 .466,61$ & 98,32 & $11.939 .113,19$ \\
$\mathbf{2 0 1 4}$ & $2.275 .128,00$ & 82,40 & $4.497 .139,27$ \\
$\mathbf{2 0 1 5}$ & $2.206 .720,56$ & 64,79 & $3.472 .782,07$ \\
$\mathbf{2 0 1 6}$ & $2.257 .859,78$ & 53,80 & $3.897 .614,74$ \\
$\mathbf{2 0 1 7}$ & $2.511 .521,24$ & 55,18 & $3.891 .600,80$ \\
$\mathbf{2 0 1 8}$ & $2.763 .808,74$ & 40,80 & $3.928 .327,40$ \\
$\mathbf{2 0 1 9}$ & $2.886 .451,48$ & 36,09 & $4.362 .546,11$ \\
Total & $\mathbf{4 2 . 4 9 1 . 6 9 9 , 8 8}$ & - & $\mathbf{8 9 . 0 2 7 . 8 3 7 , 5 8}$ \\
\hline
\end{tabular}

Fonte: Elaboração própria com base na calculadora do cidadão correção de valores.

No período analisado, o valor total dos repasses apresentou um crescimento de $90,76 \%$ de aumento, ou seja, quase o dobro do valor, caso se leve em consideração a correção de valores. Já o valor total das parcelas apresentou um aumento de 105,85\% na correção.

O gráfico abaixo indica a evolução no crescimento do atendimento da educação infantil da rede municipal. De 2008 até o ano de 2019, houve um crescimento bastante expressivo, de $181,69 \%$ no total geral de matrículas da educação infantil.

Gráfico 5 - Total de Matrículas educação Infantil de Rondonópolis - 2008 a 2019

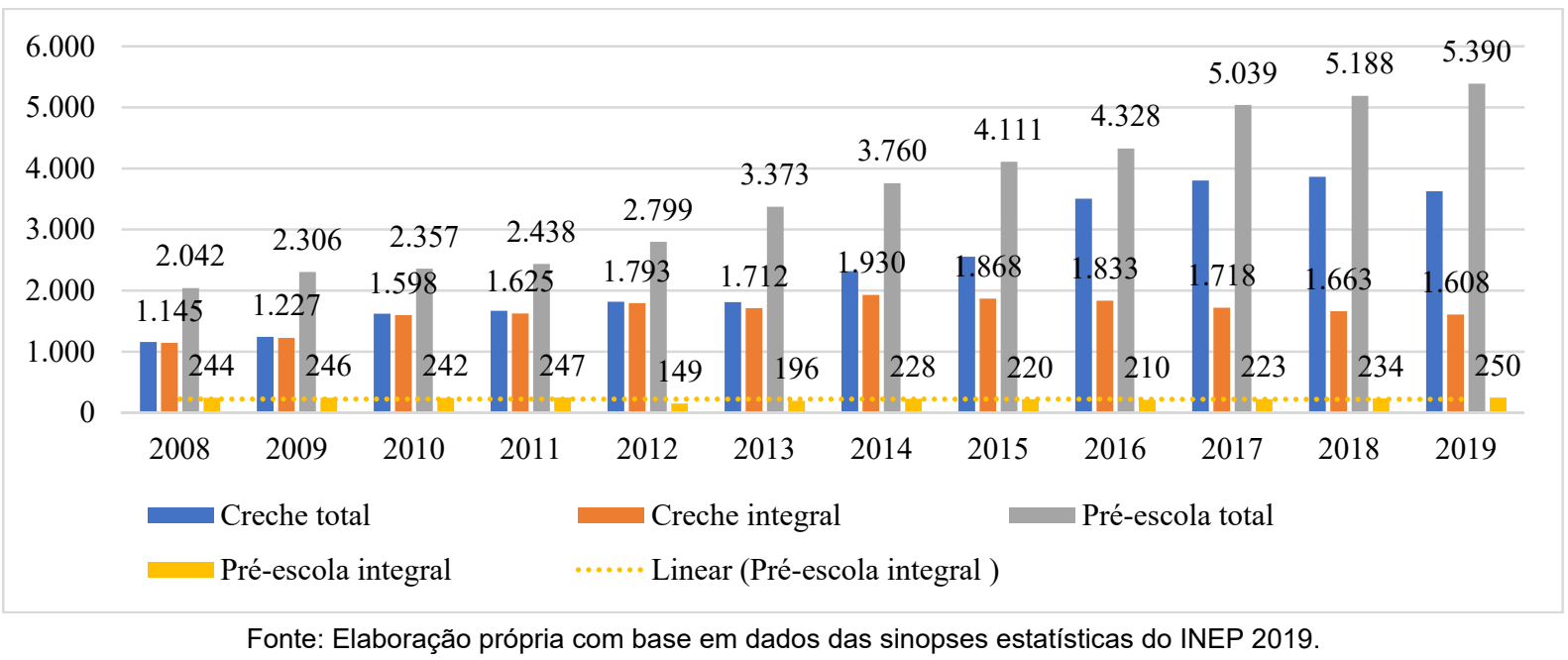

Fica explícito um baixo atendimento de educação integral para alunos da pré-escola, em que a linha de tendência quase não apresenta variação, mesmo com o aumento de $163,95 \%$ de matrículas totais na pré-escola, de 2008 para 2019. Em 2008, 11,94\% apenas das matrículas da pré-escola eram em tempo integral; em 2019, esse valor caiu para 4,6\% das matrículas em tempo integral. Mesmo com o aumento das matrículas pelo município, a 
A Privatização dos Recursos Educacionais através das Escolas Confessionais

Cáritas ainda continuou recebendo auxílio da educação infantil no município, conforme tabela abaixo:

Tabela 2 - Total de Matrículas Cáritas Diocesana entre 2008 e 2019

\begin{tabular}{lccccc}
\multirow{2}{*}{ Ano } & \multicolumn{2}{c}{ Creche } & \multicolumn{2}{c}{ Pré-escola } & Total geral \\
\cline { 2 - 4 } $\mathbf{2 0 0 8}$ & Total & Integral & Total & Integral & \\
$\mathbf{2 0 0 9}$ & 467 & 197 & 1.320 & 529 & 1.787 \\
$\mathbf{2 0 1 0}$ & 826 & 305 & 982 & 314 & 1.808 \\
$\mathbf{2 0 1 1}$ & 746 & 268 & 976 & 337 & 1.722 \\
$\mathbf{2 0 1 2}$ & 818 & 250 & 957 & 302 & 1.775 \\
$\mathbf{2 0 1 3}$ & 701 & 76 & 952 & 103 & 1.653 \\
$\mathbf{2 0 1 4}$ & 531 & - & 872 & - & 1.403 \\
$\mathbf{2 0 1 5}$ & 402 & - & 698 & - & 1.100 \\
$\mathbf{2 0 1 6}$ & 161 & - & 727 & - & 888 \\
$\mathbf{2 0 1 7}$ & 56 & - & 696 & - & 752 \\
$\mathbf{2 0 1 8}$ & 364 & - & 201 & - & 565 \\
$\mathbf{2 0 1 9}$ & 244 & - & 324 & - & 568 \\
& 238 & - & 322 & - & 560
\end{tabular}

Fonte: Elaboração própria com base em dados das sinopses estatísticas do INEP 2019.

É nítido que, no ano de 2008, as matrículas realizadas na instituição correspondiam a $55,82 \%$ das realizadas no município na educação infantil. O gráfico abaixo mostra essa escala de declínio no atendimento, tanto parcial quanto integral de matrículas.

Gráfico 6 - Total de Matrículas educação Infantil da Cáritas Diocesana - 2008 a 2019

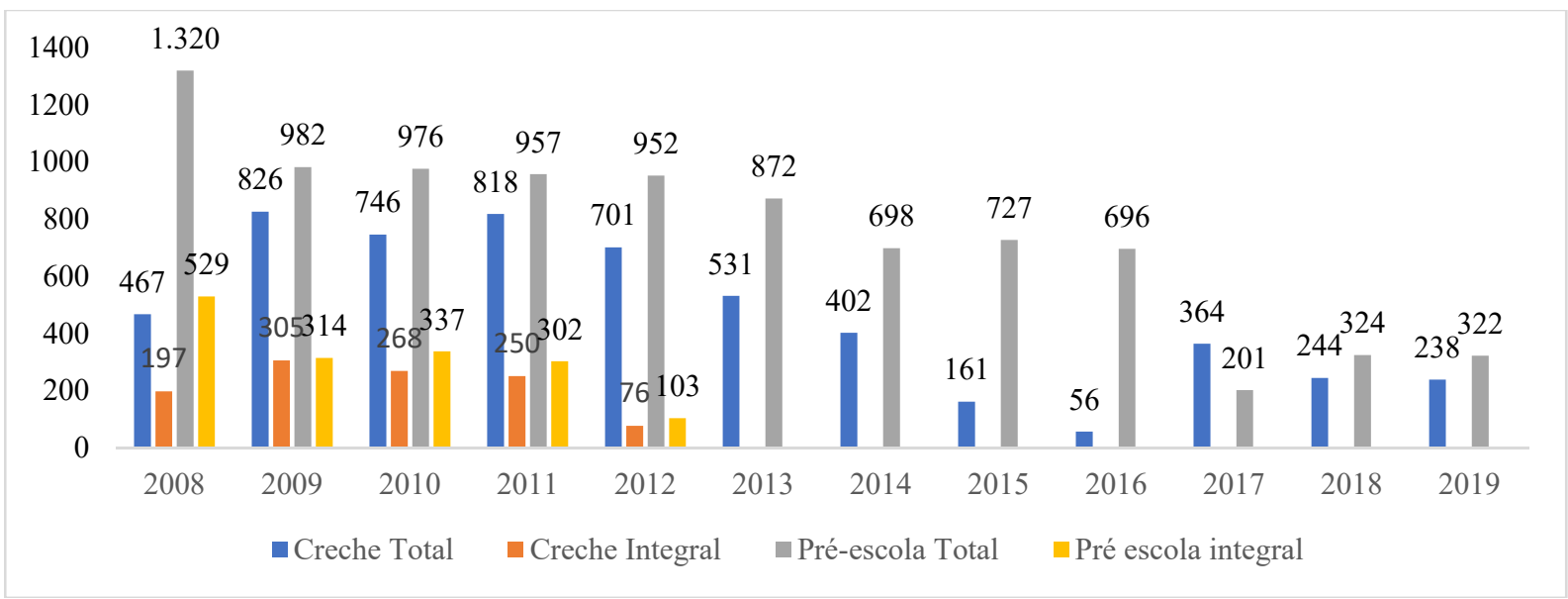

Fonte: Elaboração própria com base em dados das sinopses estatísticas do INEP 2019.

Como mostra o Gráfico 6, o valor repassado em 2020 foi 156,73\% maior do que o de 2008, mas, por outro lado, dois fatores chamam atenção: a queda no número de matrículas para mais da metade e o fornecimento da educação em tempo integral (creche e pré-escola) foi extinto em 2012, ou seja, a instituição diminuiu gradativamente o atendimento às crianças 
A Privatização dos Recursos Educacionais através das Escolas Confessionais

do município, apresentando uma queda de $68,66 \%$, em comparação ao período entre 2008 e 2019 , no total de matrículas, enquanto o valor do repasse aumentou mais de $100 \%$.

Tabela 3 - Custo aluno anual Educação Infantil Cáritas X município entre 2008 e 2019

\begin{tabular}{|c|c|c|c|c|c|}
\hline Ano & $\begin{array}{l}\text { Número Total de } \\
\text { Alunos Município }\end{array}$ & $\begin{array}{c}\text { Número de } \\
\text { Alunos Cáritas }\end{array}$ & $\begin{array}{l}\text { Valor Aluno Anual } \\
\text { Cáritas }\end{array}$ & $\begin{array}{c}\text { Valor Aluno Anual } \\
\text { Cáritas } \\
\text { Corrigido }\end{array}$ & $\begin{array}{l}\text { Valor }{ }^{5} \text { Aluno } \\
\text { Municipal }\end{array}$ \\
\hline 2008 & 3.201 & 1.787 & 615,55 & $1.737,14$ & -6 \\
\hline 2009 & 3.548 & 1.808 & $3.281,93$ & $8.563,89$ & $9.279,36$ \\
\hline 2010 & 3.977 & 1.722 & $2.090,59$ & $5.491,83$ & $12.223,64$ \\
\hline 2011 & 4.107 & 1.775 & $4.304,22$ & $10.140,35$ & $17.214,88$ \\
\hline 2012 & 4.616 & 1.653 & $2.177,85$ & $4.908,53$ & $11.655,00$ \\
\hline 2013 & 5.184 & 1.403 & $4.074,45$ & $8.509,68$ & $11.455,00$ \\
\hline 2014 & 6.079 & 1.100 & $2.068,29$ & $4.088,29$ & $11.464,00$ \\
\hline 2015 & 6.667 & 888 & $2.485,04$ & $4.724,11$ & $10.238,00$ \\
\hline 2016 & 7.834 & 752 & $3.002,47$ & $5.144,55$ & $9.618,00$ \\
\hline 2017 & 8.841 & 565 & $4.445,17$ & $7.141,80$ & $9.776,00$ \\
\hline 2018 & 9.053 & 568 & $4.865,86$ & $7.849,73$ & $11.231,00$ \\
\hline 2019 & 9.017 & 560 & $5.154,37$ & $7.790,25$ & $11.779,00$ \\
\hline
\end{tabular}

Fonte: Elaboração própria com base em dados das sinopses estatísticas do INEP 2019 (cálculos feitos pelos autores).

A tabela acima mostrou o custo por aluno anual de acordo com o valor do repasse e o número de alunos matriculados na instituição; percebe-se que, com o passar dos anos, o número de alunos diminuiu significativamente, porém o valor por aluno teve um aumento considerável na comparação entre 2008 e 2019.

\section{Considerações finais}

O texto aborda um breve histórico das instituições confessionais de ensino no País, bem como os embates travados por suas entidades representativas e aquelas que empunharam a bandeira de defesa da escola pública, em especial no movimento Constituinte que culminou na Constituição Federal de 1988 e na elaboração da LDBEN, Lei nº 9 394/1996. Ao assegurar a destinação de recursos públicos também a escolas comunitárias, confessionais ou filantrópicas, definidas em lei, o setor privado, mesmo que declarado sem fins lucrativos, tem acessado recursos públicos e contribuído para a privatização da educação pública, como pode ser o caso detectado com a Cáritas Diocesana de Rondonópolis. Essa entidade recebe subvenção financeira anualmente por meio de leis municipais, nas quais são estabelecidos os recursos a serem transferidos pela Secretaria Municipal de Educação para a instituição. Vale ressaltar aqui que a entidade atende a outros setores e recebe fundos de outras secretarias além da educação, como por exemplo a Secretaria de Assistência Social.

5 Correções feitas no IPCA.

6 Não disponível no SIOPE. 
A Privatização dos Recursos Educacionais através das Escolas Confessionais

Inicialmente, a instituição atendia um número expressivo de alunos da educação infantil, tanto na creche quanto na pré-escola, e recebia um valor que equivalia a $\mathrm{R} \$ 615,55$ por aluno anualmente, valor que, corrigido atualmente, corresponderia a $R \$ 1.737,14$. Em 2019, o valor anual por aluno repassado à instituição equivale a $\mathrm{R} \$ 7.790,25$, representando um aumento de $348,45 \%$ de 2008 até 2019 . Por outro lado, o valor aluno ano da rede pública municipal de Rondonópolis em 2008 não foi informado, mas o de 2009 equivalia a R\$ 9.279,36 e, o de 2019 , a $R \$ 11.779,00$.

Quanto a matrículas na creche e pré-escola na Cáritas Diocesana, houve uma queda significativa para mais da metade, a partir de 2013; o atendimento na creche e pré-escola integral foi extinto a partir de 2012, conforme dados das sinopses estatísticas do INEP. Em contrapartida, no mesmo período, houve aumento no atendimento na rede pública municipal, na creche e na pré-escola, a partir do ano de 2013, com tendência à estabilidade no atendimento à creche integral, a partir de 2010. A ampliação do acesso, sobretudo na préescola, a partir de 2013, pode estar relacionada ao cumprimento da Emenda Constitucional $n^{\circ} 59 / 2009$ e à Lei $n^{\circ} 12.796$, de 04 de abril de 2013, pelo município, em atenção à escolarização obrigatória de 04 a 17 anos e à universalização até 2016.

Mesmo que os valores repassados à instituição sejam menores que o valor aluno gasto anualmente pelo poder público municipal, impacta diretamente no orçamento da Secretaria de Educação por apresentar uma porcentagem alta de repasses e um número baixo de atendimentos atualmente. Os dados coletados apresentam grande potencial para análises futuras a partir de indicadores objetivos com relação a acesso, permanência, qualidade da educação, perfil do aluno atendido pela Cáritas, número de crianças na faixa etária de zero a 3 e de 4 a 5 anos de idade fora da escola, para melhor apurar se a privatização via subvenção à entidade filantrópica caracteriza transferência de responsabilidade do Estado para o atendimento aos direitos sociais básicos e, por consequência, se pode acabar ferindo o direito constitucional à educação.

\section{Referências}

ADRIÃO, Theresa. Dimensões e Formas da Privatização da Educação no Brasil: caracterização a partir de mapeamento de produções nacionais e internacionais. Currículo sem fronteiras, v. 18, p. 8-28, 2018.

ANDERSON, Perry. Balanço do Neoliberalismo. In: BORÓN, Atílio; SADER, Emir (Org.). Pósneoliberalismo. As Políticas Sociais e o Estado Democrático. 8. ed. São Paulo: Paz e Terra, 1995. p. 9-34.

BALL, Stephen; YOUDELL, Deborah. Privatización encubierta en la educación pública, Internacional de la Educación. Bruselas, 2007.

BORÓN, Atílio A. sociedade civil depois do dilúvio neoliberal. In: GENTILI, Pablo; SADER, Emir (Org.). Pós-neoliberalismo: as políticas sociais e o Estado Democrático. Rio de Janeiro: Paz e Terra, 1995.

BORÓN, Atílio A. Tras el Búho de Minerva. Mercado contra democracia refrencia en el capitalismo de fin de siglo, Buenos Aires: Fondo de Cultura Económica, 2000. 
A Privatização dos Recursos Educacionais através das Escolas Confessionais

BOURDIEU, Pierre. Escritos de Educação. Organizadores Maria Alice Nogueira e Afranio Catani. 15. ed. Petrópolis: Vozes, 2014.

BRASIL. Presidência da República. Casa Civil. Constituição da República Federativa do Brasil de 1988. Diário Oficial da União, Brasília, 1988. Disponível em: http://www.planalto.gov.br/ ccivil_03/Constituicao/ Constituiçao.htm. Acesso em: 02 jul. 2021.

BRASIL. Presidência da República. Lei $n^{\circ}$ 8.069, de 13 de julho de 1990. Dispõe sobre o Estatuto da Criança e do Adolescente e dá outras providências. Diário Oficial da União, Brasília, 16 jul. 1990. Retificado em 27.9.1990.

BRASIL. Presidência da República. Emenda Constitucional n 14, de 12 de setembro de 1996. Modifica os arts. 34, 208, 211 e 212 da Constituição Federal e dá nova redação ao art. 60 do Ato das Disposições constitucionais Transitórias. Diário Oficial da União, Brasília, 13 set. 1996a.

BRASIL. Presidência da República. Lei n 9.394, de 20 de dezembro de 1996. Estabelece as diretrizes e bases da educação nacional. Diário Oficial da União, Brasília, 23 dez. 1996b.

BRASIL. Presidência da República. Lei n 9.424, de 24 de dezembro de 1996. Dispõe sobre o Fundo de Manutenção e Desenvolvimento do Ensino Fundamental e de Valorização do Magistério, na forma prevista no art. $60, \S 7^{\circ}$, do Ato das Disposições Constitucionais Transitórias, e dá outras providências. Diário Oficial da União, Brasília, 26 dez. 1996c.

BRASIL. Presidência da República. Decreto $n^{\circ} 2.264$, de 27 de junho de 1997. Regulamenta a Lei $n^{\circ}$ 9.424, de 24 de dezembro de 1996, no âmbito federal, e determina outras providências. Diário Oficial da União, Brasília, 28 jun. 1997. Revogado pelo Decreto $n^{\circ}$ 10.656, de 2021.

BRASIL. Presidência da República. Lei n 11.079, de 30 de dezembro de 2004. Institui normas gerais para licitação e contratação de parceria público-privada no âmbito da administração pública. Diário Oficial da União, Brasília, 31 dez. 2004.

BRASIL. Presidência da República. Emenda Constitucional n 53, de 19 de dezembro de 2006. Dá nova redação aos arts. $7^{\circ}, 23,30,206,208,211$ r 212 da Constituição Federal e ao art. 60 do Ato das Disposições Constitucionais Transitórias. Diário Oficial da União, Brasília, 20 dez. 2006.

BRASIL. Presidência da República. Lei no 11.494, de 20 de junho de 2007. Regulamenta o Fundo de Manutenção e Desenvolvimento da Educação Básica e de Valorização dos Profissionais da Educação - FUNDEB. Diário Oficial da União, Brasília, 21 jun. 2007a.

BRASIL. Presidência da República. Decreto $n^{\circ}$ 6.253, de 13 de novembro de 2007. Dispõe sobre o Fundo de Manutenção e Desenvolvimento da Educação Básica e de Valorização dos Profissionais da Educação - FUNDEB, regulamente a Lei no 11.494, de 20 de junho de 2007, e dá outras providências. Diário Oficial da União, Brasília, 14 nov. 2007b. Revogado pelo Decreto $n^{\circ}$ 10.656, de 2021.

BRASIL. Presidência da República. Emenda Constitucional $n^{\circ}$ 59, de 11 de novembro de 2009. Diário Oficial da União, Brasília, 12 nov. 2009. 
A Privatização dos Recursos Educacionais através das Escolas Confessionais

BRASIL. Presidência da República. Lei n 12.796, de 4 de abril de 2013. Altera a Lei n 9.394 , de 20 de dezembro de 1996, que estabelece as diretrizes e bases da educação nacional, para dispor sobre a formação dos profissionais da educação e dar outras providências. Diário Oficial da União, Brasília, 5 abr. 2013.

BRASIL. Presidência da República. Emenda Constitucional nº 108, de 26 de agosto de 2020. Diário Oficial da União, Brasília, 27 ago. 2020a.

BRASIL. Presidência da República. Lei n 14.113, de 25 de dezembro de 2020. Regulamenta o Fundo de Manutenção e Desenvolvimento da Educação Básica e de Valorização dos Profissionais da Educação (Fundeb), de que trata o art. 212-A da Constituição Federal; revoga dispositivos da Lei $n^{\circ} 11.494$, de 20 de junho de 2007; e dá outras providências. Diário Oficial da União, Brasília, 25 dez. 2020b.

CURY, Carlos R. Jamil. O público e o privado na história da educação brasileira. In: LOMBARDI, José Claudinei et al. (Org.). 0 público e o privado na história da educação brasileira - concepções e práticas educativas. Campinas: Autores Associados; Histedbr; Unisal, 2005.

CURY, Carlos R. Jamil. A educação básica como direito. Cadernos de Pesquisa, São Paulo, v. 38, n. 134, p. 293-303, maio/ago. 2008.

DARDOT, Pirre; LAVAL, Christian. A nova razão do mundo - Ensaio sobre a sociedade neoliberal. São Paulo: Boitempo, 2016.

GOHN, Maria da Glória. Movimentos sociais e educação. 5. ed. São Paulo: Cortez, 2001.

MONLEVADE, João. Educação pública no Brasil: Contos e descontos. Ceilandia: Idéia, 1997.

PERONI, Vera. Política Educacional e papel do Estado no Brasil dos anos 1990. São Paulo: Xamã, 2003.

PINTO, José Marcelino de Rezende. O FINANCIAMENTO DA EDUCAÇÃO NA CONSTITUIÇÃO FEDERAL DE 1988: 30 ANOS DE MOBILIZAÇÃO SOCIAL. Educação \& Sociedade, Campinas, v. 39, n. 145, p. 846-869, dez. 2018.

PUELLO-SOCARRÁS, José Francisco. Gramática del Neo-Liberalismo. Genealogía y claves para su desciframiento. Econ. Gest. Desarro, Cali (Colombia), n. 4, p. 141-181, nov. 2008.

ROMANELLI, Otaiza de Oliveira. História da educação no Brasil. 21 ed. Petrópolis: Vozes, 1998.

RONDONÓPOLIS. Gabinete do Governo Municipal. Lei n 9.077, de 01 de dezembro de 2016. Fica instituído o Sistema de Educação do Município de Rondonópolis, estado de Mato Grosso, e dá outras providências. 01.12.2016. DIORONDON, Rondonópolis, 14 dez. 2016.

RONDONÓPOLIS. Gabinete do Governo Municipal. Lei n 9.352, de 17 de julho de 2017. Dispõe sobre a organização, estrutura, funcionamento e a composição do Conselho Municipal de Educação de Rondonópolis-MT, de acordo com a Lei de Diretrizes e Bases da Educação Nacional e da Lei Municipal n 9.077/2016. DIORONDON, Rondonópolis, 2017. 
A Privatização dos Recursos Educacionais através das Escolas Confessionais

SAMPAIO, Gabriela T. C; OLIVEIRA, Romualdo P. de. Dimensões da desigualdade educacional no Brasil. RBPAE, v. 31, n. 3, p. 511-530, set./dez. 2015.

SOUSA, Bartolomeu José Ribeiro de; SILVA, Regina Aparecida da; LORENSINI, Sandra Regina Geiss. Sistemas e conselhos municipais de educação. Curitiba: Appris, 2016.

Marilda de Oliveira Costa é doutora em Educação pela UFRGS. Professora do Programa de Pós-graduação (Mestrado em Educação) da Universidade do Estado de Mato GrossoUNEMAT. Cáceres, Mato Grosso, Brasil.

ORCID: https://orcid.org/0000-0001-6859-0041

E-mail: marilda.costa@unemat.br

Tiago dos Santos Rodrigues é graduado em pedagogia pela Universidade Federal de Rondônia, professor da rede pública municipal de Cáceres-MT, Aluno do Programa de Pósgraduação Mestrado em Educação da Universidade do Estado de Mato Grosso-Unemat.

ORCID: https://orcid.org/0000-0001-7219-9598

E-mail: tiago.rodrigues@unemat.br 